\title{
Effect of Different Organic Sources on Nutrient Dynamics and Microbial Count of Black Gram [Vigna mungo (L.) Hepper]
}

\author{
N. Vinod Kumar, M.B. Patil, B.T. Nadadouda, Ramesh Beergi
}

10.18805/LR-4782

\begin{abstract}
Background: Concerning fertilization, the pulse crops are more responsive to organic manures but indiscriminate and continuous use of chemical fertilizers has venomous effects on physical, chemical and biological properties of the soil thereby affecting the sustainability of crop production, besides causing environmental pollution.

Methods: The study aimed at understanding the effect of different organic amendments on nutrient dynamics of black gram (Vigna mungo), which was carried out at the IFS unit, College of Agriculture, Vijayapur, during Kharif-2019 to study the effect of different combinations of organic sources on nutrient availability, nutrient uptake and soil microbial load in black gram.

Result: The application of vermicompost + ghanajeevamrutha @ 100\% RDP + Rhizobium + PSB recorded significantly higher soil organic carbon (SOC) $(0.70 \%)$, soil available nitrogen $\left(291.39 \mathrm{~kg} \mathrm{ha}^{-1}\right)$, phosphorus $\left(36.30 \mathrm{~kg} \mathrm{ha}^{-1}\right)$ and potassium (580.53 kg ha-1) and significantly higher uptake of nutrients i.e., nitrogen (52.07 and $75.43 \mathrm{~kg} \mathrm{ha}^{-1}$ ), phosphorus (10.12 and $\left.16.08 \mathrm{~kg} \mathrm{ha}^{-1}\right)$ and potassium ( 37.67 and $55.42 \mathrm{~kg} \mathrm{ha}^{-1}$ ) at 45 and 75 DAS compared to all other treatments. Similarly, application of FYM + vermicompost @ 100\% RDP + Rhizobium + PSB has recorded the highest microbial count of bacteria [24.40 $\times 10^{6}$ CFU (Colony Forming Units) $\left.\mathrm{g}^{-1}\right]$, fungi $\left(17.0 \times 10^{3} \mathrm{CFU} \mathrm{g}^{-1}\right)$ and actinomycetes $\left(7.50 \times 10^{3} \mathrm{CFU} \mathrm{g}{ }^{-1}\right)$, demonstrating the importance of usage of organics for improving the nutrient availability, uptake and microbial load in black gram.
\end{abstract}

Key words: Black gram, Farmyard manure, Ghanajeevamrutha, Rhizobium, Vermicompost.

\section{INTRODUCTION}

Pulses play an important role in Indian agriculture for sustainable production, improvement in soil health and environmental safety and a cheaper source of quality protein which is nearly three times more than that of cereals to overcome malnutrition among vegetarians. They are more responsive to organic manures but the haphazard use of chemical fertilizers also had adverse effects on soil physical, chemical and biological properties thereby affecting the sustainability of crop production, besides causing environmental pollution (Harshitha et al., 2021). Hence, there is a scope to improve productivity under the organic production system by enhancing soil fertility and productivity with increasing soil organic carbon, soil moisture storage capacity of crops at different stages.

Black gram [Vigna mungo (L.) Hepper] is one of the most important pulse crops of India, with an annual production of 21.00 lakh tonnes from 35.15 lakh ha with average productivity of $655.0 \mathrm{~kg} \mathrm{ha}^{-1}$ (Anonymous, 2018). Though black gram has spread across the country with a significant area, its overall production is very poor owing to its poor productivity even among the different pulses. Cultivation on marginal lands with poor nutrient status is the primary constraint for its poor productivity. Being a member of Leguminosae, it can meet its nitrogen requirements while focus needs to be diverted towards other important nutrients.

Hazards like soil salinization, soil erosion, reduction in the groundwater levels and desertification have increased rapidly over the last four decades with continuous practice
Department of Agronomy, College of Agriculture, University of Agricultural Sciences, Vijayapur-586 102, Karnataka, India.

Corresponding Author: N. Vinod Kumar, Department of Agronomy, College of Agriculture, Professor Jayashankar Telangana State Agricultural University, Rajendranagar-500 030, Hyderabad, Telangana, India. Email: vinodnallagatla@gmail.com.

How to cite this article: Kumar, N.V., Patil, M.B., Nadadouda, B.T. and Beergi, R. (2022). Effect of Different Organic Sources on Nutrient Dynamics and Microbial Count of Black Gram [Vigna mungo (L.) Hepper]. Legume Research. DOI: 10.18805/LR-4782.

Submitted: 02-09-2021 Accepted: 20-12-2021 Online: 29-01-2022

of intensive farming techniques, whose eye is primarily on increasing production with the least focus on sustainability. There is an urgent need for the integrated use of organics and chemicals to achieve higher productivity besides maintaining sustainability. The real potential of organic farming can be witnessed in rainfed areas where the SOM and SOC are lesser as the drylands are well adapted to organic farming (Baswapoor, 2010). Given this, the present investigation was carried out to know the effect of soil organic manures on nutrient availability, nutrient uptake and soil microbial load of black gram.

\section{MATERIALS AND METHODS}

The field experiment was conducted during Kharif-2019 at the College of Agriculture, Vijayapur, UAS, Dharwad, Karnataka to study the effect of different organic amendments on nutrient dynamics of black gram (Vigna 
mungo). The soil of the experimental field was classified as clayey with a pH of 7.82 , SOC content of $0.57 \%, \mathrm{~N}(262 \mathrm{~kg}$ $\left.\mathrm{ha}^{-1}\right), \mathrm{P}_{2} \mathrm{O}_{5}\left(32.50 \mathrm{~kg} \mathrm{ha}^{-1}\right)$ and $\mathrm{K}_{2} \mathrm{O}\left(390 \mathrm{~kg} \mathrm{ha}^{-1}\right)$ contents. The site falls under a semi-arid climate with rainfall of 576.80 $\mathrm{mm}$. The maximum and minimum of $35.1^{\circ} \mathrm{C}$ and $21.6^{\circ} \mathrm{C}$ temperature were recorded during the experimental year.

The black gram variety TAU-1 was sown with a spacing of $45 \mathrm{~cm} \times 10 \mathrm{~cm}$ with 12 treatments consisting of organic amendments laid out in RCBD with three replications. The recommended dose of phosphorus (RDP) for black gram was supplemented with different combinations of soil organic manures with equal proportions based on their $P$ content. The required quantity of organic manures viz., FYM, vermicompost, ghanajeevamrutha were applied uniformly as per the treatments and incorporated into the soil three weeks before sowing. The number of organic manures was worked out equivalent to the recommended dose of fertilizers (20-50-0 kg ha-1 of $\mathrm{N}-\mathrm{P}_{2} \mathrm{O}_{5}-\mathrm{K}_{2} \mathrm{O}$ ).

Five plants from the representative plots were chosen from which the number of pods harvested per plant, the average number of pods per plant, number of seeds per plot and seed index $(\mathrm{g})$, seed yield from the net plot $\left(\mathrm{kg} \mathrm{ha}^{-1}\right)$, harvest index $(\mathrm{HI})\left(\mathrm{kg} \mathrm{ha}^{-1}\right)$ was calculated.

Plant samples were collected treatment-wise from all the replications, cleaned, dried in the oven at $60-70^{\circ} \mathrm{C}$ till constant weight is attained and ground to a fine powder in Willey mill with stainless steel blades for nutrient analysis. Nitrogen content in the plant was estimated by adopting the modified Micro Kjeldahl method (Jackson, 1973), phosphorus content was determined by a vanadomolybdophosphoric acid yellow colour method using a spectrophotometer at $470 \mathrm{~nm}$ wavelength (Olsen et al., 1954) and potassium content was determined by flame photometer after making suitable dilutions (Jackson, 1973).

The representative soil samples from each replication were collected randomly after harvest with the help of an auger. The samples were mixed homogenously, a composite sample was prepared, air-dried and then dried in the hot air oven at $105^{\circ} \mathrm{C}$ for 24 hours and passed through a $2 \mathrm{~mm}$ sieve for the determination of SOC, available nitrogen, phosphorus and potassium by adapting standard procedures. The SOC was determined by Walkley and Black's (1934) wet oxidation method and was expressed in percentage. The soil available nitrogen was determined by the alkaline potassium permanganate method (Subbiah and Asija,1956) and expressed in $\mathrm{kg} \mathrm{ha}^{-1}$. The soil available phosphorus was determined by Olsen et al. (1954) method using a spectrophotometer and expressed in $\mathrm{kg} \mathrm{ha}^{-1}$ and the soil available potassium was extracted with neutral normal ammonium acetate was estimated using flame photometer (Jackson, 1973) and expressed in $\mathrm{kg} \mathrm{ha}^{-1}$. The soil microbial population count was taken after harvest following the procedures given by Aneja, 2003.

The treatment details include:

$\mathrm{T}_{1}$ : FYM+ vermicompost based on $100 \% \mathrm{RDP}$; $\mathrm{T}_{2}$ : Vermicompost+ ghanajeevamrutha based on $100 \% \mathrm{RDP}$;
$\mathrm{T}_{3}$ : FYM+ ghanajeevamrutha based on $100 \%$ RDP;

$\mathrm{T}_{4}: \mathrm{FYM}+$ vermicompost based on $50 \% \mathrm{RDP}$;

$\mathrm{T}_{5}$ : Vermicompost+ ghanajeevamrutha based on $50 \%$ RDP;

$\mathrm{T}_{6}$ : FYM+ ghanajeevamrutha based on $50 \%$ RDP;

$\mathrm{T}_{7}$ : $\mathrm{FYM}+$ vermicompost based on $100 \% \mathrm{RDP}+$ Rhizobium+PSB;

$\mathrm{T}_{8}$ : Vermicompost+ ghanajeevamrutha based on $100 \%$ RDP+ Rhizobium+ PSB;

$\mathrm{T}_{9}$ : FYM+ ghanajeevamrutha based on $100 \% \mathrm{RDP}+$ Rhizobium+ PSB;

$\mathrm{T}_{10}: \mathrm{FYM}+$ vermicompost based on $50 \% \mathrm{RDP}+$ Rhizobium+ PSB; $\mathrm{T}_{11}$ : Vermicompost+ ghanajeevamrutha based on $50 \%$ RDP+ Rhizobium+ PSB;

$\mathrm{T}_{12}:$ FYM + ghanajeevamrutha based on $50 \%$ RDP+ Rhizobium+ PSB.

\section{RESULTS AND DISCUSSION \\ Yield}

Among the organic manures, application of $P$ as vermicompost + ghanajeevamrutha based on $100 \%$ RDP + Rhizobium + PSB resulted in higher seed yield $(701.33 \mathrm{Kg}$ $\mathrm{ha}^{-1}$ ) and recorded higher yield attributing characters i.e., number of pods per plant (19.33), number of seeds per pod (6.33), haulm yield (2038.7 kg ha-1) and seed yield compared to other treatments (Table 2).

\section{Nutrient availability}

Among the different combination of organic manures, application of vermicompost + ghanajeevamrutha @ 100\% RDP + Rhizobium + PSB has recorded higher SOC $(0.70 \%)$, available nitrogen (291.39 kg ha-1), phosphorus $(36.30 \mathrm{~kg}$ $\left.\mathrm{ha}^{-1}\right)$ and potassium ( $\left.580.53 \mathrm{~kg} \mathrm{ha}^{-1}\right)$ as compared to other treatments (Table 1).

\section{Nutrient uptake}

Among the different combinations of organic manures, application of $\mathrm{P}$ as vermicompost + ghanajeevamrutha @

Table 1: Effect of organic sources on yield parameters.

\begin{tabular}{lcccc}
\hline Treatments & $\begin{array}{c}\text { No. of } \\
\text { pods } \\
\text { per plant }\end{array}$ & $\begin{array}{c}\text { No. of } \\
\text { seeds } \\
\text { per pod }\end{array}$ & $\begin{array}{c}\text { Haulm } \\
\text { yield } \\
\left(\mathrm{kg} \mathrm{ha}^{-1}\right)\end{array}$ & $\begin{array}{c}\text { Seed } \\
\text { yield } \\
\left(\mathrm{kg} \mathrm{ha}^{-1}\right)\end{array}$ \\
\hline $\mathrm{T}_{1}$ & 14.67 & 5.33 & 1707.33 & 610.00 \\
$\mathrm{~T}_{2}$ & 15.67 & 5.67 & 1807.33 & 634.00 \\
$\mathrm{~T}_{3}$ & 15.00 & 5.33 & 1728.00 & 622.00 \\
$\mathrm{~T}_{4}$ & 7.33 & 4.67 & 1390.33 & 408.33 \\
$\mathrm{~T}_{5}$ & 9.00 & 5.00 & 1432.33 & 491.33 \\
$\mathrm{~T}_{6}$ & 8.33 & 4.00 & 1426.00 & 411.00 \\
$\mathrm{~T}_{7}$ & 17.00 & 6.00 & 1838.00 & 659.33 \\
$\mathrm{~T}_{8}$ & 19.33 & 6.67 & 2038.67 & 701.33 \\
$\mathrm{~T}_{9}$ & 18.00 & 6.33 & 1890.00 & 680.00 \\
$\mathrm{~T}_{10}$ & 10.33 & 4.67 & 1480.33 & 537.00 \\
$\mathrm{~T}_{11}$ & 13.00 & 5.00 & 1631.67 & 592.67 \\
$\mathrm{~T}_{12}$ & 11.67 & 5.00 & 1532.33 & 573.00 \\
$\mathrm{SEm} \pm$ & 0.61 & 0.40 & 60.81 & 30.54 \\
$\mathrm{CD}(\mathrm{p}=0.05)$ & 1.79 & 1.17 & 178.37 & 89.60 \\
\hline
\end{tabular}


$100 \%$ RDP + Rhizobium + PSB $\left(\mathrm{T}_{8}\right)$ has resulted in higher uptake of nutrients i.e., nitrogen (52.07 and $\left.75.43 \mathrm{~kg} \mathrm{ha}^{-1}\right)$, phosphorus (10.12 and $\left.16.08 \mathrm{~kg} \mathrm{ha}^{-1}\right)$ and potassium (37.67 and $55.42 \mathrm{~kg} \mathrm{ha}^{-1}$ ) by the black gram at 45 and 75 DAS respectively (Table 3 ).

Application of FYM + ghanajeevamrutha @ 100\% RDP + Rhizobium + PSB as well as FYM+ vermicompost @ 100\% $\mathrm{RDP}+$ Rhizobium + PSB has resulted in highest nitrogen and phosphorus uptake at both 45 and 75 DAS which was at par with treatment $\mathrm{T}_{8}$ (Fig 1).

\section{Microbial load}

The field experiment was conducted during Kharif season of 2005 and 2006 at the research farm of SKN College of Agriculture, Jobner, RAU, Bikaner on sandy loam soil.

The higher microbial population in the soil is a positive indicator of soil quality which can be enhanced through the

Table 2: Effect of organic sources on availability of nutrients and organic carbon in the soil.

\begin{tabular}{lcccc}
\hline Treatments & $\begin{array}{c}\mathrm{OC} \\
(\%)\end{array}$ & $\begin{array}{c}\mathrm{N} \\
\left(\mathrm{kg} \mathrm{ha}^{-1}\right)\end{array}$ & $\begin{array}{c}\mathrm{P}_{2} \mathrm{O}_{5} \\
\left(\mathrm{~kg} \mathrm{ha}^{-1}\right)\end{array}$ & $\begin{array}{c}\mathrm{K}_{2} \mathrm{O} \\
\left(\mathrm{kg} \mathrm{ha}^{-1}\right)\end{array}$ \\
\hline $\mathrm{T}_{1}$ & 0.58 & 243.45 & 31.79 & 526.33 \\
$\mathrm{~T}_{2}$ & 0.60 & 262.93 & 33.33 & 556.80 \\
$\mathrm{~T}_{3}$ & 0.59 & 250.51 & 32.97 & 541.13 \\
$\mathrm{~T}_{4}$ & 0.52 & 204.93 & 21.82 & 421.47 \\
$\mathrm{~T}_{5}$ & 0.55 & 217.70 & 26.48 & 463.10 \\
$\mathrm{~T}_{6}$ & 0.53 & 209.12 & 23.98 & 429.97 \\
$\mathrm{~T}_{7}$ & 0.61 & 273.06 & 34.17 & 566.66 \\
$\mathrm{~T}_{8}$ & 0.70 & 291.39 & 36.30 & 580.53 \\
$\mathrm{~T}_{9}$ & 0.67 & 282.37 & 35.09 & 573.00 \\
$\mathrm{~T}_{10}$ & 0.56 & 226.95 & 29.40 & 474.03 \\
$\mathrm{~T}_{11}$ & 0.57 & 237.82 & 31.46 & 512.23 \\
$\mathrm{~T}_{12}$ & 0.57 & 232.31 & 30.80 & 500.40 \\
$\mathrm{SEm} \pm$ & 0.02 & 8.19 & 1.04 & 20.71 \\
$\mathrm{CD}(\mathrm{p}=0.05)$ & 0.06 & 24.04 & 3.05 & 60.74 \\
\hline
\end{tabular}

addition of organic matter to the soil. Among the different combination of organic manures, application of FYM + vermicompost @ 100\% RDP + Rhizobium + PSB has resulted in highest bacteria, fungi and actinomycetes population $\left(24.4 * 10^{6} \mathrm{CFU} \mathrm{g}^{-1}, 17.00 * 10^{4} \mathrm{CFU} \mathrm{g}^{-1}, 7.50 * 10^{3}\right.$ CFU g ${ }^{-1}$, respectively) which was at par with the treatments FYM + ghanajeevamrutha @ 100 \% RDP + Rhizobium + PSB and vermicompost + ghanajeevamrutha @ $100 \%$ RDP + Rhizobium + PSB were applied (Table 4).

The higher seed yield of black gram might be due to the prolonged and steady availability of major nutrients during the crop growth period with the inclusion of nutrientrich organics viz. FYM, vermicompost, Ghanajeevamrutha. The pivotal role of Rhizobium in fixation of atmospheric nitrogen might have enhanced the supply and translocation of $\mathrm{N}$ which influenced the development of photosynthetic organs and inoculation of PSB to solubilize the insoluble $P$ through the production of organic acids and have some augmenting effect on the native Rhizobium population besides playing a vital role in nodule formation (Sailaja Kumari and Usha Kumari, 2002, Kumar et al., 2016 and Wagadre et al., 2010).

Higher yield attributes due to the application of jeevamrutha might be attributed to the solubilisation of nutrients in soil and absorption of nutrients and moisture (Sutar et al., 2019). Further, the elements viz., nitrogen, phosphorus and potassium present in the protoplasm assisted in physiological functions of plants such as chlorophyll and protein synthesis which in turn boosted the plant growth. The results are corroborative with the findings of Bhatt et al. (2012) and Jagdeesh et al (2018).

The maximum availability of nutrients and SOC in the soil might be ascribed to the addition of nutrients into the soil which remained unutilized even after crop harvest and thus improved the soil fertility status and soil physical, chemical and biological properties (Meena and Ram, 2016). It might also be due to the inclusion of organic sources which

Table 3: Uptake of nutrients at 45 and 75 DAS as influenced by different combinations of organic sources of nutrient supply.

\begin{tabular}{|c|c|c|c|c|c|c|}
\hline \multirow{2}{*}{ Treatments } & \multicolumn{2}{|c|}{ Nitrogen $\left(\mathrm{kg} \mathrm{ha}^{-1}\right)$} & \multicolumn{2}{|c|}{ Phosphorus (kg ha-1) } & \multicolumn{2}{|c|}{ Potassium $\left(\mathrm{kg} \mathrm{ha}^{-1}\right)$} \\
\hline & 45DAS & 75 DAS & 45 DAS & 75 DAS & 45DAS & 75 DAS \\
\hline $\mathrm{T}_{1}$ & 42.35 & 65.02 & 8.77 & 13.27 & 30.41 & 48.76 \\
\hline $\mathrm{T}_{2}$ & 46.19 & 67.99 & 9.25 & 14.56 & 32.33 & 50.31 \\
\hline $\mathrm{T}_{3}$ & 44.05 & 67.30 & 9.20 & 14.04 & 31.50 & 49.69 \\
\hline $\mathrm{T}_{4}$ & 30.19 & 52.37 & 6.35 & 10.43 & 18.33 & 43.26 \\
\hline $\mathrm{T}_{5}$ & 32.00 & 54.77 & 7.28 & 11.47 & 20.75 & 45.81 \\
\hline $\mathrm{T}_{6}$ & 31.39 & 53.60 & 7.37 & 10.96 & 19.70 & 44.16 \\
\hline $\mathrm{T}_{7}$ & 48.08 & 70.27 & 9.57 & 15.02 & 33.86 & 52.37 \\
\hline $\mathrm{T}_{8}$ & 52.07 & 75.43 & 10.12 & 16.08 & 37.67 & 55.42 \\
\hline $\mathrm{T}_{9}$ & 49.87 & 72.40 & 9.84 & 15.17 & 35.51 & 54.15 \\
\hline $\mathrm{T}_{10}$ & 36.05 & 55.84 & 7.73 & 12.01 & 26.85 & 46.79 \\
\hline$T_{11}$ & 39.34 & 60.10 & 8.26 & 13.08 & 29.56 & 49.57 \\
\hline $\mathrm{T}_{12}$ & 38.68 & 59.04 & 7.89 & 12.43 & 28.93 & 47.62 \\
\hline SEm \pm & 1.44 & 2.63 & 0.29 & 0.38 & 0.88 & 1.49 \\
\hline$C D(p=0.05)$ & 4.21 & 7.74 & 0.86 & 1.14 & 2.58 & 4.39 \\
\hline
\end{tabular}




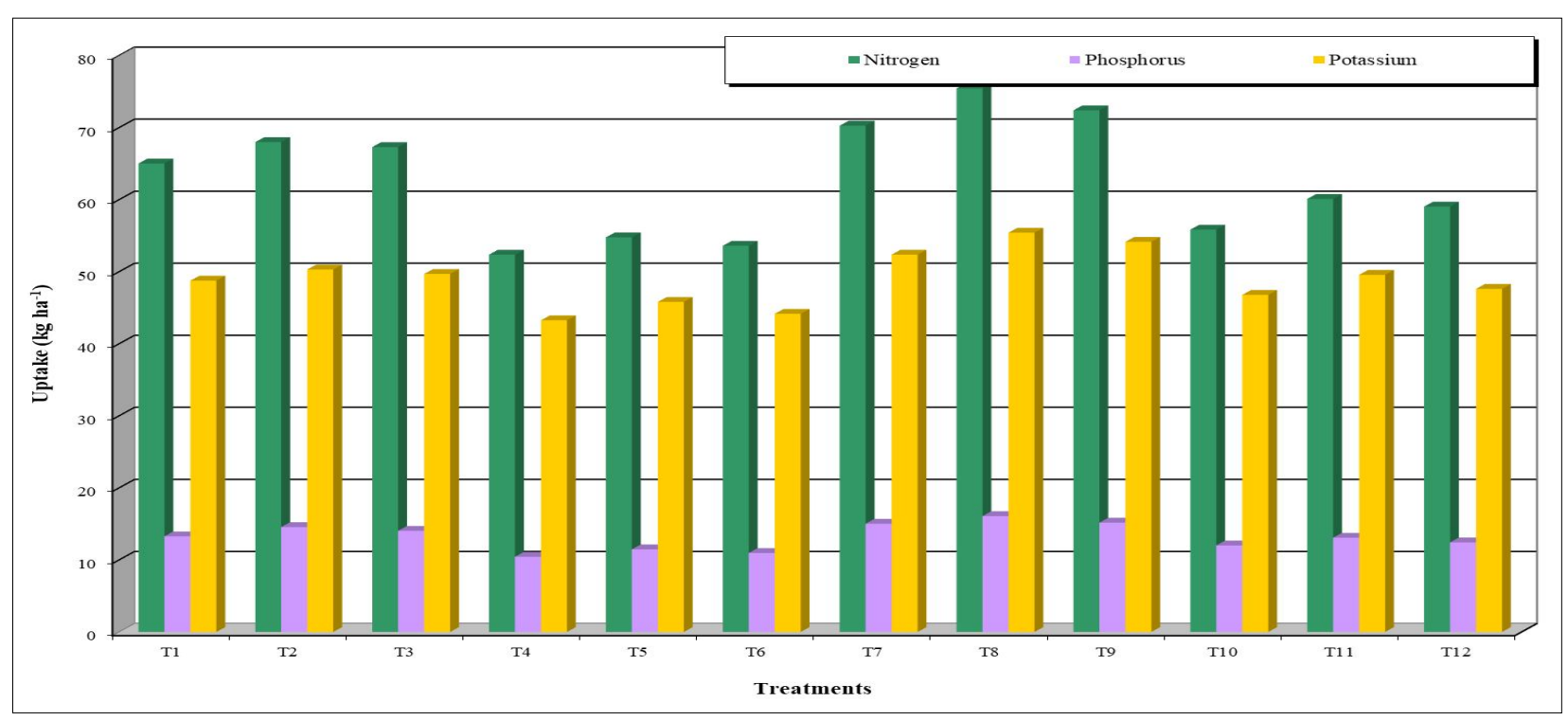

Fig 1: Effect of organic sources on nutrient supply and uptake of $N, P$ and $K$ by the crop at 45 and 75 DAS

Table 4: Influence of different organic sources on microbial load (Bacteria*10 $0^{6} \mathrm{CU} \mathrm{g}^{-1}$, Fungi* $10^{4} \mathrm{CFU} \mathrm{g}^{-1}$ Actinomycetes* $10^{3} \mathrm{CFU} \mathrm{g}^{-1}$ ) in the soil after the crop harvest.

\begin{tabular}{lccc}
\hline \multirow{2}{*}{ Treatment } & \multicolumn{3}{c}{ Population counted } \\
\cline { 2 - 4 } & Bacteria & Fungi & Actinomycetes \\
\hline $\mathrm{T}_{1}$ & 21.0 & 14.3 & 6.4 \\
$\mathrm{~T}_{2}$ & 21.7 & 15.6 & 6.6 \\
$\mathrm{~T}_{3}$ & 21.5 & 14.5 & 6.5 \\
$\mathrm{~T}_{4}$ & 18.2 & 11.0 & 4.6 \\
$\mathrm{~T}_{5}$ & 18.8 & 11.8 & 5.4 \\
$\mathrm{~T}_{6}$ & 18.6 & 11.1 & 5.1 \\
$\mathrm{~T}_{7}$ & 24.4 & 17.00 & 7.50 \\
$\mathrm{~T}_{8}$ & 23.12 & 15.90 & 7.00 \\
$\mathrm{~T}_{9}$ & 23.7 & 16.6 & 7.2 \\
$\mathrm{~T}_{10}$ & 19.6 & 12.1 & 5.7 \\
$\mathrm{~T}_{11}$ & 20.4 & 13.5 & 6.1 \\
$\mathrm{~T}_{12}$ & 20.1 & 12.7 & 5.9 \\
$\mathrm{SEm} \pm$ & 0.81 & 0.46 & 0.27 \\
$\mathrm{CD}(\mathrm{p}=0.05)$ & 2.37 & 1.34 & 0.80 \\
\hline $\mathrm{Wh}$ & & &
\end{tabular}

Where,

FYM: Farm yard manure;

RDP: Recommended dose of phosphorus (50 kg ha-1);

PSB: Phosphorus solubilizing bacteria.

promoted the nutrient supplying capacity of the soil and build-up of more and more soil microorganisms and mineralized organic nitrogen resulting in the production of auxins and gibberellins by PSB which might have also helped in increased root growth, $\mathrm{N}$ absorption and higher $\mathrm{N}$ content in black gram seed. Additionally, Rhizobium inoculation helped the plant in effective atmospheric $\mathrm{N}$ fixation, resulting in higher seed nitrogen content substantially (Bhalu et al. 1995; Yogananda et al., 2020).
When the organics are applied, nutrients will be released slowly reducing the nutrient losses because of the greater absorption of nutrients as a result of increased cation exchange capacity that is enhanced with organic manure application. Thus, plant nutrients will be available for a long period in sufficient quantity facilitating greater absorption and uptake of nutrients as per the demand. (Kumawat, 2009; Tyagi et al. 2018 and Chaudhary et al., 2018).

The addition of FYM, vermicompost and ghanajeevamrutha to the soil resulted in enhanced microbial activity and release of nitrogenous compounds from organic carbon upon mineralization. Besides, there was an increase in nitrogenfixing bacteria which might have increased the nitrification process and released more nitrogen into the soil solution. The soil microbes which produce organic acids during their decomposition of organic matter and $\mathrm{CO}_{2}$ accelerate weathering process and convert unavailable phosphorus and potassium to available form for plants. Therefore, a higher amount of nutrients was left in the soil after maximum uptake by the crop. ET Similar results were revealed by Channagouda al. (2015) Jat et al. (2010).

\section{CONCLUSION}

Organic manures play a vital role in maintaining soil sustainability in the long term as they reduce nutrient losses and improve the SOC. They improve the nutrient content and uptake of plants because of longer availability and reduction in losses. The organic matter content of the soil is always positively correlated with the microbial population of the soil. Based on this study, it was found that the combined application of different organic manures like vermicompost, ghanajeevamrutha, FYM along Rhizobium and PSB would not only improve the nutrient availability, uptake and microbial load but also enhance the soil productivity in the black gram. 


\section{REFERENCES}

Aneja, K.R. (2003). Experiments in Microbiology and Plant Pathology. New Age International Pvt. Ltd., New Delhi.

Anonymous. (2018). Area, Production and Productivity of Green Gram Database Agriculture Survey of India, Ministry of Agriculture.

Baswapoor, S.R. (2010). Organic Farming: Status, Issues and Prospects- A Review. Agricultural Economics Research Review. 23.

Bhalu, V.B., Sadaria, S.G., Kaneria, B.B. and Khanpara, V.D. (1995). Effect of nitrogen, phosphorus and Rhizobium inoculation on yield and quality, $\mathrm{N}$ and $\mathrm{P}$ uptake and economics of black gram (Vigna mungo). Indian Journal of Agronomy. 40: 316-318.

Bhatt, P.K., Patel, P.T., Patel, B.T. and Vyas, K.G. (2012). Effect of vermicompost and phosphorus levels with PSB on growth and yield of summer green gram under North Gujarat conditions. Green Farming. 3: 666-669.

Channagouda, R.F., Babalad, H.B. and Salimath, S.B. (2015). Effect of organic farming practices on soil properties and beneficial soil micro-organism. International Journal of Forestry and Crop Improvement. 6: 1-11.

Chaudhary, M., Singh, S., Babu, S. and Prasad, M. (2018). Effect of integrated nutrient management on productivity, nutrient acquisition and economics of black gram (Phaseolus mungo L.) in an Inceptisol of eastern Uttar Pradesh. Legume Research. 41: 759-762.

Harshitha, H.G., Dayal, A., Rai, P.K. and Thomas, N. (2021). Presowing seed treatment with organic and inorganic treatments on growth, yield and yield attributes of desi chickpea (Cicer arietinum) variety (Pusa-362). Indian Journal of Plant and Soil. 33: 71-78.

Jackson, M.L. (1973). Soil Chemical Analysis, prentice hall of India, Pvt. Ltd, New Delhi. 38-82.

Jagdeesh Morya, R.K., Tripathi, Kumawat, N., Mahender Singh, R.K., Yadav, I.S., Tomar and Yogesh Kumar Sahu. (2018). Influence of organic and inorganic fertilizers on growth, yields and nutrient uptake of soybean [Glycine max L.) Merril] under Jhabua Hills. International Journal of Current Microbiology and Applied Sciences. 7: 725-730.

Jat, R.A. and Ahlawat, I.P.S. (2010). Effect of organic and sulphur fertilization in pigeonpea + groundnut intercropping system. Indian Journal of Agronomy. 55: 276-281.
Kumar, M., Singh, P.K., Dubey, S.N. and Singh, S.P. (2016). Effect of integrated nutrient management on growth and yield of black gram. The Journal of Rural and Agricultural Research. 16: 8-11.

Kumawat., Sharma, O.P. and Kumar, R. (2009). Effect of organic manures, PSB and phosphorus fertilization on yield and economics of mungbean [Vigna radiata (L.) Wilczek]. Environment and Ecology. 27: 5-7.

Meena, B.S. and Ram, B. (2016). Effect of integrated nutrient management on productivity, soil fertility and economics of black gram (Vigna mungo) varieties under rainfed conditions. Legume Research., 39: 268-273.

Olsen, S.R., Cole, C.V., Watanabe, F.S. and Dean, L.A. (1954). Estimation of available phosphorus in soils by extraction with sodium bicarbonate. USDA circular 939. U. S. Government Printing Office, Washington D.C. 81-84.

Sailaja Kumari, M.S. and Usha Kumari, K. 2002. Effect of vermicompost enriched with rock phosphate on the yield and uptake of nutrients in cowpea (Vigna unguiculata L.). Journal of Tropical Agriculture. 40: 27-30.

Subbiah, B.V. and Asija, G.L. (1956). A rapid procedure for estimation of available nitrogen in soils. Current Science. 25: 259-260.

Sutar, R., Sujith, G.M and Devakumar, N. (2019). Growth and yield of Cowpea [Vigna unguiculata (L.) Walp] as influenced by jeevamrutha and panchagavya application. Legume Research. 42: 824-828.

Tyagi P.K. and Singh V.K. (2018). Effect of integrated nutrient management on growth, yield and nutrient uptake of summer black gram (Vigna mungo). Annals of Plant and Soil Research. 21: 30-35.

Wagadre, N., Patel, M.V. and Patel, H.K. (2010). Response of summer green gram (Vigna radiata L.) to vermicompost and phosphorus with and without PSB inoculation. State Level Seminar on "Organic Farming" Navsari, Gujarat., 111-113.

Walkey, A and Black, I.A. (1934). An examination of the Degtjareff method for determining soil organic matter and a proposed modification of the chromic acid titration method. Soil Science. 37: 29-37.

Yogananda, S.B., Thimmegowda, P. and Shruthi, G.K. (2020). Performance of Cowpea [Vigna unguiculata (L.) Walp] under organic production system in Southern dry zone of Karnataka. Legume Research. 43: 229-234. 